\title{
New paths for the assessment of Brazilian post- graduation and challenges in the Nursing area
}

\author{
Cristina Garcia de Lima Parada ${ }^{a, b}$ (iD \\ Luciane Prado Kantorskia,c ii \\ Lucia Yasuko Izumi Nichiataa,d
}

How to cite this article:
Parada CGL, Kantorski LP, Nichiata LYI. New
paths for the assessment of Brazilian post-
- graduation and challenges in the Nursing
area [Editorial]. Rev Gaúcha Enferm.
2020;41(esp):e20190359. doi: https://doi.
org/10.1590/1983-1447.2020.20190359

This special issue of Revista Gaucha de Enfermagem commemorates the 68th anniversary of the Nursing School (EENF) and the 20th of the Postgraduate Program in Nursing (PPGENF) of the Federal University of Rio Grande do Sul (UFRGS). It presents the results of original unpublished researches, accounts of experiments and systematic revision of literature on matters that have contributed to the transition and transference of knowledge in the different contexts of nursing practice. This initiative is intended to lend visibility to academic scientific production facing the challenge of alignment with the precepts defined for evaluation of Brazilian post-graduation conducted by CAPES, which have been realigned in 2019.

In July 2019, the stricto sensu postgraduate system in Brazil amounted to 6,935 courses: 3,652 master's degree, 2,401 doctorates, 851 professional master's and 31 professional doctorates. As at 2017, 61,158 master's (50,316 academic and 10,842 professional) and 21,591 doctorates ${ }^{(1)}$, so this year target 14 of the National Postgraduate Plan (2011-2020) was met partially, relative to formation of masters and doctors ${ }^{(2)}$.

The excellent results obtained by Brazilian post-graduation over the years and the important role of evaluation in its improvement have been recognized. Nevertheless, it is evident that, given the system's expansion, the assessment model in place so far has reached its point of exhaustion and must be revised.

In this context, Coordination for the Improvement of Higher Education Personnel (CAPES) approved a new evaluation system to be used in the four years 2017-2020, reducing the number of items as compared to the former system. The proposal is to focus on the quality of formation of masters and doctors; emphasis on the items that most discriminate the quality of programs; greater emphasis on evaluation of results than processes; attaching greater value to the protagonism of areas in the construction of indicators adequate to each modality, respecting specifics while maintaining comparability between them. Coordination of the nursing area has worked with the program coordinators at different times, to arrive at a definition of assessment indicators, which were applied upon evaluating the mid-term, it being necessary to go through adjustment prior to the four-year assessment.

In the environment of this new cycle of evaluation, three challenges stand out regarding post-graduation in nursing: program planning, in connection with Development Plans of entities to which they are linked, social impact and focus on graduates. It is considered that strategic planning of the program is an important tool to foster its growth and qualification. Thus, postgraduate program planning in the nursing area must be inserted into the situation and the specificity of each university, taking into account the situation, the national and international contexts, regional demands, economic and social challenges, health indicators and the social and development needs of the Unified Health System (SUS).

\footnotetext{
a Coordenação de Aperfeiçoamento de Pessoal de Nível Superior (CAPES), Diretoria de Avaliação, Coordenação da Área de Enfermagem. Braślila, Distrito Federal, Brasil.

b Universidade Estadual Paulista Júlio de Mesquita Filho (UNESP), Faculdade de Medicina, Departamento de Enfermagem. Botucatu, São Paulo, Brasil.

'Universidade Federal de Pelotas (UFPel), Faculdade de Enfermagem. Pelotas, Rio Grande do Sul, Brasil.

¿ Universidade de São Paulo (USP), Escola de Enfermagem. São Paulo, São Paulo, Brasil.
} 
Each program must plan its future strategically and make it clear how it did so, considering the international challenges in the nursing field in the production of knowledge, theoretical, methodological and technological qualification of its students and graduates and their social insertion. It must also take into account meeting current and/or future demands for national, regional or local development, by forming professionals capable of solving problems innovatively.

Planning of each program must be aimed at the development of good health practice, in order to transfer knowledge and its application in health services, as well as attending to challenges rising from complex problems related to caregiving, management and policies in the sector. The point of departure should be self-evaluation, and this will be one of the items evaluated, considering processes, procedures, instruments and results of the programs focusing on student formation and intellectual production, from the perspective of social and/or scientific and/or technological and/or professional insertion.

Regarding the graduates, an increase in the number of masters and doctors, academics and professionals, in decision-making positions, with their incorporation into work environments corresponding to their areas of interest, and therefore increase in their income. In addition, approval for public positions and changes in health services implemented by these graduates are relevant points for establishing the economic impact produced by the programs. It will therefore become increasingly important for programs to follow up on their graduates, to identify professional insertion and nucleation they produce. It may be useful to watch over the results of their research, funding obtained, insertion in postgraduate programs and the labor market and effective orientation of pupils, among other relevant activities.

The challenge includes aspects relative to qualitative assessment of production. Programs will be evaluated taking into account their most relevant dissertations and theses and, in the case of nursing, the criteria for this are being put together by program coordinators and coordination of the area evaluated - CAPES. Evaluation of bibliographical production will be rendered feasible by Qualis Reference, based on bibliometric indicators that consider the number of times the periodical is quoted. The programs will be evaluated in the body of publications and will indicate the most relevant among them. It is a challenge for post-graduation in nursing that teachers produce with their students and graduates and that such productions be of quality so as to constitute a source of knowledge for Brazilian and international researchers, expanding the possibilities of interlocution and strengthening nursing as a science. With regard to technical production, mainly of professional programs, there is also a challenge involved in implementing coparticipation of teachers and students and graduates. Equally relevant are aspects such its exact distinction as a product of post-graduation, the ways to divulge and inform about this production, to enable identification of its political, social and economic impact.

In this latter aspect, one must refer to the challenge of demonstrating the social impact of the program, which must reflect on the formation of qualified human resources to be proactive and integrated in society, in improvement of public management and reduction of social debt, as well as formation of a public to make use of the scientific resources and knowledge stemming from research. Included in this field are services and attention to the community developed with effective participation of the program's teachers and students, seeking solutions and/or answers to situations in everyday practice in health entities in the context of SUS, teaching and the challenges of action for implementation of public policies.

Finally, it is necessary to stress that research in Brazil is mostly carried out within post-graduation and that challenges must be tackled with the participation of students and teachers, with the support of administrative technical personnel. In this way the need to value these actors is reaffirmed, as is understanding that the first goal of post-graduation is qualified formation for production of knowledge. To this end, it is imperative that resources are ensured, as well as adequate infrastructure to foster science, technology and innovation in Brazil.

\section{口 REFERENCES}

1. Coordenação de Aperfeiçoamento de Pessoal de Nível Superior [Internet]. Brasília, DF: Capes; c2016-2019 29 de julho de 2019 [citado 2019 jul 29 ]. Plataforma Sucupira: cursos avaliados e reconhecidos; [aprox. 1 tela]. Available from: https://sucupira.capes.gov.br/sucupira/public/consultas/coleta/programa/quantitativos/ quantitativoAreaAvaliacao.jsf

2. Coordenação de Aperfeiçoamento de Pessoal de Nível Superior (BR). Plano Nacional de Pós-Graduação - PNPG 2011-2020. Brasília, DF: CAPES; 2010 [citado 2019 jul 15]. v.1. https://www.capes.gov.br/images/stories/download/Livros-PNPG-Volume-l-Mont.pdf

\section{Corresponding author}

Cristina Garcia de Lima Parada

E-mail: cristina.parada@unesp.br 